\section{A growing resistance}

Bruce Handler reports from Rio de Janeiro on recent developments involving the controversial German-Brazilian nuclear deal

Attempts by the Carter Administration in the United States to undermine the controversial nuclear technology agreement between West Germany and Brazil are resulting in precisely the opposite of what Washington wants. Brazil are resulting in precisely the go through with the atomic pact. Formerly divergent internal currents in Brazil are rallying behind the Brazilian government in defence of the agreement with Germany. And other Latin American countries-especially Argentina, which has always been considered Brazil's principal rival-are sticking up for Brazil in an unusual display of Latin American solidarity.

Part of Jimmy Carter's election campaign platform consisted of promises to oppose the spread of nuclear technology, especially in the underdeveloped Third World. And just a few days after taking office, he dispatched his Vice President, Walter Mondale, to West Germany to ask Chancellor Helmut Schmidt to reconsider German plans, under the nuclear agreement, to aid Brazil in developing its own fullfuel cycle. This German knowhow is to allow Brazil to enrich its own uranium for use in electricity-producing nuclear reactors, but it also will make Brazil theoretically capable of producing plutonium-a key ingredient in nuclear weapons.

After some initial backtracking, however, Germany said it will go ahead with the Brazilian agreement as planned. Brazil declared flatly that it "sees no possibility" of altering or delaying the pact, as the United States wants. And Paulo Nogueira Batista, the head of the Brazilian government's nuclear power company, Nuclebras, told the press: "The agreement is being carried out on schedule, and in some cases you could say we are making even more progress than we expected."

Brazil's foreign minister, Antonio F. Azeredo da Silveira, did say later, though, that Brazil is willing to discuss "global aspects" of the problem of the spread of nuclear technology. This, the minister noted, ought to prove to President Carter that Brazil intends to act like a responsible, adult nation. Azeredo da Silveira invited the US Secretary of State, Cyrus Vance, to Brazil for talks, and it appears Vance will come.
The attempted pressure-play from Washington resulted in a remarkable outpouring of unified internal support for Brazil's authoritarian, military-run government, which had pressed hard to get the nuclear agreement with Germany in the first place. The actual agreement was signed in mid-1975, but the Brazilians had begun secretive negotiations with the Germans several years earlier.

Marcos Freire, a senator from the sole opposition political party permitted in Brazil, said: "The United States has no moral authority to interfere with the nuclear treaty." He speculated that "powerful economic interests" might be behind Washington's meddling, in view of the fact that the total value of contracts to be signed under the Brazilian-German agreement is conservatively estimated at $\$ 5,000$ million.

Another member of the opposition party, Representative Joao Cunha, said Brazilian President Ernesto Geisel, "speaking in the name of all Brazil's 110 million citizens, should repudiate this US manoeuvre."

Even Brazil's academic and scientific community, which under the current government tends to stay as far away from politics as possible, has spoken up with regard to the nuclear agreement. "This government is correct in not permitting outside interference in affairs over which it has exclusive sovereignty," said Professor Marcelo Dami, a physicist from Sao Paulo. Dami made it clear that he did not like the secretive way in which the government had gone about negotiating the agreement with the Germans and also that he has reservations about the type of fuel that was chosen for atomic reactors that are to be built in Brazil under the pact. "But disagreements of this nature now must be put in the background, in view of higher national interests that are at stake," he said.

Helio Jaguaribe, a political scientist whom some members of Brazil's military regime regard as a "dangerous intellectual," also came out in full support of the government. "President Geisel deserves the warmest applause from all Brazilians for the firm position he has taken in supporting the agreement," he declared. "President Carter's concern about the proliferation of nuclear weapons is fully valid. But Brazil has no nuclear weapons, and it does not intend to have them."

$\mathrm{He}$ said a distinction has to be made between stopping the proliferation of nuclear weapons and "the desire of the superpowers to maintain a monopoly on nuclear technology." The Brazilian government, furthermore, was "absolutely right in not signing the Nuclear Non-Proliferation Treaty," since to do so "would perpetuate the underdevelopment of third world countries."

Unexpected defence for Brazil came from across the border in Argentina, which until now has been wary, to say the least, of its fast-developing neighbour's nuclear energy programmes and goals. Argentina began its own nuclear programme in the 1960 s and was regarded as the most important country in Latin America in terms of atomic development until the GermanBrazilian deal emerged.

"Argentina supports the Brazilian government in the nuclear field," declared the newspaper La Opinion of Buenos Aires, which is said to reflect the official line of President Jorge Videla's military-run regime. "The US offensive against Brazil, which is aimed at stopping progress on its plan with Germany to install eight more nuclear reactors, a uranium enrichment plant and a fuel reprocessing plant, is a blow which could be fatal to Brazil's nuclear industry. What happens to Brazil today could happen to Argentina tomorrow."

And in a statement that must have surprised a lot of Brazilians, $L a$ Opinion wrote: "Brazil is not just any developing country. It is a coparticipant in the destinies of Argentina, in the Latin American context."

Amid the renewed debate surrounding the Brazilian-German nuclear pact, Brazilian government officials have hastened to repeat this country's justification for seeking the agreement in the first place:

- Brazil produces only $20 \%$ of the crude oil it needs every year. Its domestic coal is of low quality. Its remaining major potential hydroelectric sources are in the Amazon jungle, thousands of miles away from its centres of population and industry. Therefore, Brazil must develop nuclear energy as a source of electricity.

- Brazil must possess the knowhow for supplying itself with nuclear fuel. Despite a US offer to furnish already processed enriched uranium (with no transfer of technology) for Brazilian reactors, Brazil cannot run the risk of remaining dependent on foreign sources for energy. (Look what happened to the United States during the Arab oil boycott, a much heard Brazilian argument goes.)

- Brazil is a peaceful country. It doesn't need or want an atom bomb, and it would not divert resources from vital social and economic needs to build one. And besides, the safeguards in 
the German-Brazilian nuclear agreement were approved by the International Atomic Energy Agency, with both the United States and the Soviet Union voting in favour.

Although none of the reactors or fuel processing equipment specified in the nuclear agreement actually has been built yet, the accord most definitely is being carried out, as the head of Nuclebras, Nogueira Batista, said.

More than 100 Brazilian scientists are taking specialised training in Germany, and the Brazilian government has allocated generous amounts of funds to local universities to expand programmes in nuclear-related fields of science. German atomic technicians already are working in Brazil. Adverts in newspapers are seeking secretaries fluent in Portuguese and German. Six subsidiary firms have been set up under Nuclebras to implement the agreement. These companies are to operate in areas such as nuclear technology and engineering, heavy equipment manufacturing, uranium prospecting and mining, and isotope enrichment.

Financing arrangements already have been completed for the first two 1.3 million-kilowatt German reactors that will be built in Brazil, with knowhow and components to be supplied by Germany's Kraftwerke Union. Related contracts have been signed between other German and Brazilian companies and consortiums, private as well as governmental, for site clearing and preliminary building construction.

Unofficial calculations show that over $\$ 1,000$ million-worth of cruzeiros, marks and dollars have been spent or committed under the GermanBrazilian nuclear agreement so far.

\section{Talk about the weather}

Unusual weather encourages discussion of weather modification. Colin Norman reports on the debate in the western United States

THE strange weather patterns which have brought freezing temperatures and record snowfalls to the eastern United States this winter have brought the opposite problem to many western states. A severe drought is threatening agricultural production in California and it may disrupt hydroelectric power supplies in the Pacific northwest. And in the Rocky Mountain states the snow cover is so thin that the spring runoff is unlikely to be sufficient for crop irrigation, ranching, industry and domestic needs. In short, while the east is bracing for possible floods when the thaw comes, the west is facing a debilitating drought.

One consequence of this topsy-turvy pattern is that considerable public interest has been rekindled in the use of weather modification techniques to try to increase snowfall on the western mountains before spring arrives. The most dramatic expression of such interest came in Colorado earlier this month, when the state legislature approved a bill to provide up to $\$ 250,000$ for cloud seeding operations in the state. A major effort is also under way in Utah, some seedings have taken place in California, Oregon and Washington state, and an cxtensive long-term weather modification programme is also under discussion for the upper Colorado basin. One product so far is the generation of a good deal of local controversy.

This year's anomalous weather patterns have been caused by a stationary ridge of high pressure off the west coast, which has disrupted the normal westerly winds. Usually, the prevailing westerlies bring winter storms in from the Pacific to dump snow on the mountains in the western states, but this year the winds have been deflected northward and have looped through Canada to descend on the eastern United States. The consequences in the east have ben dramatic; in the west they have been more subtle.

Very little rain or snow has fallen in the Pacific northwest since September, and some industries which depend on hydroelectricity may face power reductions of $25 \%$ by the end of this month. Fire hazards abound in forest areas which are usually under several feet of snow at this time of the year. In California, domestic water supplies are already being rationed in Marin County near San Fransisco, and last week the Bureau of Reclamation (an agency in the Department of Interior) notified farmers in the San Joaquin Valley that their irrigation water may be cut by $75{ }^{\prime \prime}$ later this year. California produces about 40 " $"$ of the fresh fruits and vegetables consumed in the United States. In Utah and Colorado, snowfall has been about $30-40 \%$ of normal, and as a result ranchers are selling off cattle because they cannot get sufficient feed and the winter wheat crop may be in jeopardy.

Another, more distant problem is likely to arise because spring runoff from the Colorado Rockies supplies most of the water in the Colorado River, which in turn provides much of the irrigation and drinking water for parts of Arizona, California, Nevada and northwestern Mexico. Though water now in storage in Lake Powell behind the Glen Canyon Dam and in Lake Mead behind the Hoover Dam will be sufficient to meet downstream needs for at least a couple of years, if this year's weather patterns are repeated next winter, some serious problems could occur. Small wonder, therefore, that weather modification techniques are attracting attention.
They will not provide salvation, however.

The legislation in Colorado will provide funds for massive cloud seeding operations during the rest of this winter on the western slopes of the Rocky Mountains, using silver iodide generators on the ground. Some airborne seeding will also take place in the eastern plains. In Utah, routine cloud seeding, sponsored by the Utah Water Conservation Board, has been undertaken for the past three years, and this year it is being expanded to cover nearly two-thirds of the state.

It should be noted, however, that cloud seeding can only increase natural precipitation; it cannot create snow when the conditions are not right for snowfall. Thus, the Colorado and Utah cloud seeding efforts will only be conducted if westerly winds return to bring snow clouds to the Rockies. According to a spokesman for the Colorado Water Conservation Board, the seeding programme will, at best, increase spring runoff this year by about 200,000 acre feet, an amount which will certainly not wipe out the anticipated shortages.

In a normal year, spring runoff from the Colorado Rockies into the Colorado River amounts to about 11 or 12 million acre fect. This year, Colorado officials are estimating that the runoff will be down to about 7 million acre feet.

Although any contribution from cloud seeding would be a help, environmentalists in Colorado vigorously opposed the emergency legislation when it was under consideration in the state legistature. Kevin Markey, a representative of Friends of the Earth, said last week, for example, that "it isn't emergency cloud seeding legislation, it's emergency political legislation to let everyone know that the governor and legislature are doing something". Markey argues that the time and effort spent on cloud seeding would be better devoted to water conservation programmes.

Environmentalists are particularly concerned about plans for a possible 